\title{
MAKING SCIENTIFIC CONCEPTS EXPLICIT THROUGH EXPLANATIONS: SIMULATIONS OF A HIGH-LEVERAGE PRACTICE IN TEACHER EDUCATION
}

\begin{tabular}{l}
\hline \multicolumn{1}{c}{ Dr. Valeria M. Cab } \\
\\
\hline A R T I C L E I N F O \\
Original Research \\
Received: July, 21.2018. \\
Revised: October, 30.2018. \\
Accepted: November, 11.2018. \\
doi:10.5937/ijcrsee1803035C \\
UDK \\
371.13/.14
\end{tabular}

Keywords:

Explanation,

Simulations,

High-leverage practice,

Science Education.
A B S T R A C T

There is a current research interest into high-leverage teaching practices which are geared towards making concepts explicit to learners. Explanations are a common practice in science education for sharing and constructing meaning with students. However, current studies insufficiently articulate a framework for understanding pre-service teachers' explanations; neither do they assess the practical criteria for development. This article documents various criteria for pre-service science teachers' explanations as related to the cognitive science literature and their assessment in the context of an instrument designed for teacher education. A rubric was constructed which organized structural and supportive elements into three levels. A validation process is described, and its application in teacher education programs to detect possible patterns and changes in pre-service science teachers' explanations. The results show the explanation strengths of pre-service teachers working with examples, graphs and images. However, difficulties were found in using and improving analogies, metaphors, and models, and also approaching mis-conceptions as a learning opportunity. Theoretical and practical issues are discussed from a cognitive perspective. We conclude that the signaling implications of using rubrics sensitive to progress-monitoring during teacher education for high-leverage teaching practices give opportunities to simulate and rehearse practices that are highly conducive to learning.

(C) 2018 IJCRSEE. All rights reserved.

\section{INTRODUCTION}

Researchers and teacher educators seek to evaluate what educational practices are highly conducive to learning. Within which, high-leverage practices have been specifically identified (Ball and Forzani, 2011) as teaching practices with an impact on student learning, which are learned and implemented by beginner teachers (O'Flaherty and Beal, 2018). There is also increased interest in assuring teacher capacity development during teacher

Corresponding Author

Dr. Valeria M. Cabello, Pontificia Universidad Católica de Chile, Chile

E-mail: vmcabello@uc.cl

\section{cc) (i) $\ominus$}

This work is licensed under a Creative Commons Attribution - NonCommercial - NoDerivs 4.0. The article is published with Open Access at www.ijcrsee.com education (Koteva-Mojsovska and Nikodinovska, 2015; O'Flaherty and Beal, 2018). Nonetheless, current studies insufficiently articulate a cognitive framework for understanding teachers' explanations as a means of making scientific concepts explicit. Considering that explaining is crucial for children's discovery and connecting daily life phenomena with underlying principles (Legare, Gelman and Wellman, 2010), this is problematic. Teacher explanations also form a high-leverage teaching practice (Windschitl, Thompson, Braaten and Stroupe, 2012).

Explanations are communicative actions intended to make sense of a phenomenon, divulge its meaning and make it understandable or apprehensible for learners (Thagard, 1992; Norris, Guilbert, Smith, Hakimelahi, and Phillips, 2005). It can also be understood as the act of answering a 'why?' question about phenomena (Norris et al., 2005). Explanations in teaching intend to share knowledge and un- 
derstanding with other people who have the intention of learning (Treagust and Harrison, 1999).

A common point for the development of high-leverage practices such as explanations is the relevance of practical experience for enacting teaching (Koteva-Mojsovska and Nikodinovska, 2015). However, simulations of teaching provide a systematic approach to teaching actions without the cognitive and emotional load of real classroom settings. Thus, simulations of explanations for a future classroom can be beneficial in teacher education. This particular field is being explored with respect to defining what characterizes explanation for the classroom and showing it is a learnable capacity (Charalambous, Hill and Ball, 2011). However, no studies have been conducted which formatively evaluate explanations from a cognitive perspective within science teacher education.

Consequently, there is little knowledge available for student science teachers to build explanatory capacity before they start real teaching work. Sevian and Gonsalves (2008) constructed a rubric to assess how science students communicated their research findings to diverse audiences. Although this was an advance, they did not address constructing explanations for teaching and learning, which differs in context from and purpose from explanation / communication of science between professionals or scientists.

\subsection{Explanations for teaching science and scientific explanation}

The act of explaining has captured the attention of educators, scientists and philosophers, especially regarding what defines a scientific explanation (Geelan, 2013). Diverse meanings have been given to the term explanation (Rodrigues and Pereira, 2018). Thus, it is relevant to differentiate scientific explanations from teacher explanations.

On the one hand, scientific explanations are the main product of scientific activity (Rodrigues and Pereira, 2018), usually in the form of an evidence-driven explaining statement. The purpose of such a statement is to comprehend a phenomenon and share this understanding to the scientific communities. Hence, correct scientific vocabulary is relevant (Treagust and Harrison, 1999).

On the other hand, teacher explanations for teaching science combine axioms, concepts with metaphors and analogies con- necting them to compose a coherent entity (Geelan, 2013). The purpose is to enhance understanding and lead students to construct meaning. Teacher explanations are not opposite to inquiry-based learning and other constructivist approaches, because they may not be closed and they are not limited to lecturing on a topic (Geelan, 2012).

Certainly, explanations for the classroom can be collaboratively shaped; created from parts of students' ideas and teachers' counterparts through iteration (Dawes, 2004). Consequently, explanations for teaching science differ from scientific explanations in their rigor, details and purposes (Treagust and Harrison, 1999). Furthermore, the transformation of the scientific explanation into a thoughtfully produced teaching form intended to promote learning is the main feature of a teacher explanation (Ogborn, Kress and Martins, 1996).

The synergy of learners' and teachers' ideas in generating explanations in the classroom can be achieved by teachers connecting and contrasting learners' prior ideas with the explanation. Moreover, by students questioning teachers' explanations and critically analyzing the sources of explanations, they negotiate the meaning of a shared explanation and thereby enrich them.

\subsection{Styles in science teachers explanations}

Explanations in teaching science have been considered as a way of explicating knowledge to a non-expert audience (Treagust and Harrison, 1999), but in teaching this is not the only function. Explanations for the classroom transform the expert knowledge into a different but connected type of knowledge, intelligible and more accessible for school learners (Ogborn et al., 1996). This is Pedagogical Content Knowledge (PCK); the amalgam of pedagogical and content knowledge oriented to teaching (Shulman, 1986) and meaningmaking in the classrooms, for instance through explanations.

Depending on the teacher-student interaction, there are varying styles of explanations. First, the teacher can describe the learners' emergent ideas, connecting them with scientific models - this is known as the 'thinking together' style. Second, the teacher can turn the explanation into a tale or narrative that blends the learners' point of view with the concepts (Norris et al., 2005). Third, the 
International Journal of Cognitive Research in Science, Engineering and Education (IJCRSEE), 6(3), 35-47

teacher can ask learners to communicate their ideas as the teacher would, which asks for redescription or re-interpretation of students' ideas in other scientific terms, progressively using more precise language (Ogborn et al., 1996). Thus, teacher explanation should not merely be an exposition by the teacher to an audience, but a dialogue that contrasts scientific ideas with student ideas. Indeed, learners can propose their ideas to the class in a form of an explanation (Dawes, 2004). From Feynman's work (1994) it is clear that expert explainers use their imaginary to make sense of non-observable, abstract or more difficult concepts. However, for novice learners, this task is not easy.

Ogborn et al. (1996) indicated that explanation for teaching in the science classroom might include four tasks; marking the point between what the learners know and what they will know through the explanation, constructing the entities -it means, the gestaltof the explanation, transforming learners' prior knowledge and illustrating the phenomena that can be explained. Nonetheless, there is a gap in assessing the elements that teachers use to make scientific concepts explicit to novice learners and then taking this knowledge into teacher education.

Therefore, the question arises: what are the elements of pre-service teachers' construction of explanations for the classroom? From previous works in cognitive science and science education, it is plausible to interpret some criteria for the design of an assessment instrument with formative purposes. These follow in the next section.

\subsection{Teacher explanations elements}

The elements described below are in the rubric constructed in the present study. Our objective is to use the rubric to identify and assess the components for making explanatory concepts explicit in science teacher education. Each element is given a rationale for its inclusion. The first elements refer to the structure of the explanation, and the last are supports for representing the concepts or ideas and their connections in explanations.

\subsubsection{Structure of the explanation for teaching science}

Clarity of the elements of an explanation implies that the features, patterns and struc- ture of the content are illustrative and focused (Sevian and Gonsalves, 2008). If the ideas are difficult to understand, the explainer might slow the word flow (Mohan, 2013). This facilitates using an understandable language for the learners, and concepts being presented in an appropriate vocabulary for the learners. Thus, when making a new concept explicit, it is useful first to describe the phenomenon, its characteristics and then explain the causes based on relevant scientific terminology (Wenham, 2005). Additionally, avoiding tautology in the explanation favors its clarity (Geelan, 2012).

Coherence and cohesion. Explanations do not only establish patterns or observable relationships. Explaining implies combining relationships which count as evidence for the causal reasons of a phenomenon (Windschitl, Thompson, Braaten and Stroupe, 2012). On one hand, coherence is about how the bits of the explanation are linked together to make sense (Mayer and Jackson, 2005). For instance, through cause and consequence one can make links between the parts of the explanation, exclusion or inclusion clauses, similarity, belonging, etc. On the other hand, cohesion implies connective links between the parts of the explanation that internally relates clauses and sentences (Rodrigues, 2010). Indeed, causal ties might define causality relationships between phenomena and the underlying principles (Sevian and Gonsalves, 2008).

Sequence. The organization of the elements of an explanation is crucial for effective science teaching (Mayer and Jackson, 2005). Explanations should have an organizer principle (Sevian and Gonsalves, 2008), which is usually called a sequence. Every part of the explanation should be deducible from the precursor conditions (Wu and Shah, 2004). This sequence should reduce the cognitive load for the pupils (Cook, 2006). Avoiding unneeded or disconnected details is required because an excess of information can damage qualitative understanding in explanations (Mayer and Jackson, 2005).

Accuracy. This refers to precision in the use of terms regarding current models of scientific concepts, theories or principles (Sevian and Gonsalves, 2008). Scientific accuracy is essential in making content explicit through explanations; however, simplifications are needed at times for building knowledge which is accessible to learners (Danielson, 2013).

Completeness. Sufficiency or completeness decides whether the globalization of the explanation contributes to understanding (Roth and Welzel, 2001). Are the components 
of explanations sufficient or insufficient to understand what the explainer wanted to explain? Explanations for the classroom have a teaching objective, thus, the explanation should cover thoroughly the concept(s) intended to be taught (Danielson, 2013).

Connection with learners' knowledge. This refers to building up the explanations upon students' prior knowledge and conceptrelated experiences or ideas required to connect the explanation with the learners (Ogborn et al., 1996; Treagust and Harrison, 1999; Sevian and Gonsalves, 2008). Consequently, eliciting these before presenting new ideas is crucial (Marzano, Pickering and Pollock, 2001). In cognitive terms, when new knowledge is intentionally connected with what learners already know, information retention increases (Cook, 2006). Thus, explanations should integrate or challenge students' prior ideas about the phenomena (Smith, 2000).

\subsubsection{Explanation representational supports}

Analogies, metaphors, simulations and models. Analogies and metaphors help make meaning of abstract or complex content (Aubusson, Harrison and Ritchie, 2006; Danielsson, Löfgren and Pettersson, 2018). Likewise, models and simulations stimulate inferences and conceptual insights because of the establishment of relationships between variables. They also advance the conceptual understanding of scientific phenomena that are particularly abstract or complex (Podolefsky and Finkelstein, 2007). Simulations convert static concepts into dynamic visualizations (Baglama et al., 2017), bringing concepts to "life" (Danielson, 2013). All of these elements facilitate mental imagery of the concepts leading towards understanding the explanation (Geelan, 2013; Sevian and Gonsalves, 2008).

Examples, experiments, graphs or images. Relevant imagery helps students to clarify conceptual properties or characteristics which are usually difficult to imagine in phenomena or to recall from the learners' daily life experience (Buckley, 2000; Ogborn et al., 1996). Graphs are used to show variations in information (Kozma, 2003), as well as to represent dynamics and associations in processes (Cook, 2006). These representations can help students develop insights into scientific understanding and detect gaps in their comprehension (Windschitl, Thompson, and Braaten, 2008). When explaining with images, it is relevant to point out the specific aspect of the concept being illustrated (Sevian and Gonsalves, 2008). Likewise, in experiments it is valuable to call learners' attention to the reasons the experiment processes worked or not in a defined way. Regarding knowledge structure, experts connect the explanations with the underlying principles to help learners to create mental models (Snyder, 2000).

Gestures and voice inflections. Such cues serve as emphasis variation in explanations (Mohan, 2013). Body gestures help students' comprehension processes when connecting to the discourse of the explanation (Geelan, 2013). On the contrary, gestures might be useless or distractive if they are not representing an aspect of the concept (Sevian and Gonsalves, 2008). Hand and body gestures are part of non-verbal language useful to communicate conceptual properties (Roth and Welzel, 2001). Voice changes or speech pace variation might add relevance to certain parts of the explanation and help learners to discriminate between the relevant and the irrelevant in an explanation (Sevian and Gonsalves, 2008).

Promoting learning from misconceptions. Misconceptions are understood in this article as misunderstandings of specific information (Martin, Sexton and Gerlovich, 2009). Teachers need to prevent learners from constructing common misconceptions, by inquiring, exploring and contrasting. Misconceptions are considered excellent tools to start making thinking processes visible for students; thus, misconceptions are approached as learning opportunities (Carrascosa, 2006).

\subsection{The current study}

This study explores and assesses the above elements in pre-service teachers' explanations with a rubric constructed for formative assessment during teacher education. The rubric was developed as part of a broader research into how pre-service teachers might improve in their ability to make scientific concepts explicit for learners. The rubric embodies the assumption that there are elements of explanations, which are high-leverage; these are also more difficult to use and improve by pre-service teachers.

This paper argues that the development of a rubric, which decomposes the practice of explaining concepts into several assessable elements, informed by cognitive science and science education, is a contribution for pre- 
International Journal of Cognitive Research in Science, Engineering and Education (IJCRSEE), 6(3), 35-47

service teachers' formative assessment, whilst also providing pre-classroom opportunities to rehearse and improve competencies for making concepts explicit for teaching science in classrooms. This should better prepare preservice teachers to engage in high-leverage practices, which are known to promote learners' cognitive skills and engagement (Larkin, 2017).

The research questions were: 1 . What are the elements of pre-service teachers' explanations in a simulated context? 2. Can the elements be grouped in general constructs? 3 . How can the elements be organized and improved?

\section{MATERIALS AND METHODS}

\subsection{Research design}

The study was of a pre-post design based on quantitative measurements, but also exploratory in the sense that qualitative analyses were undertaken. Thirty-eight pre-service teachers signed a consent to participate. The participants were undergraduate student science teachers in the last year of their program from three universities; they had small prior teaching experience of only a few weeks; the average age was 25 years and they belonged to low or lower-medium socio-economic status in the country, which is very similar to the background origins of in-service teachers. Around $40 \%$ identified themselves as male and $60 \%$ as female, which was also close to the distribution of the in-service science teachers working force $(38.6 \%$ and $61.4 \%$ respectively). They lived in an urban zone of the Chilean capital, Santiago.

The sampling in this study was purposive, looking for typical cases in which each university represented a unit of analysis. Additionally, the pre-service teachers invited to participate agreed to join the research project voluntarily. The process attempted to select information-rich data in accordance with Patton (2001).

The pre-service teachers joined a 10 -session peer assessment workshop, which occupied between one and two hours extra work per week. This workshop was undertaken before they started their practicum. They were asked to explain a scientific concept to a simulated classroom composed of their classmates in a microteaching episode. They then were set to discuss in groups of 4-5 partici- pants with formative peer assessment. At the end of the workshop, they performed a second microteaching episode. The micro-teaching episodes lasted from 7 to 20 minutes and were recorded for further analysis. Only 20 participants completed both episodes and at least 6 of the 10 sessions, and these constituted the final sample.

\subsection{Development and application of the assessment instrument}

Nineteen initial aspects of explanations were proposed, sourced from the literature in science education and cognitive science. There were specific elements for science education, but some of the others could also be applied to other subjects. Elements which were too wide were discarded to maintain the focus on explanations. Then the 17 aspects remaining were decomposed into three levels of completion. Each level contained observable features that could be addressed during teaching based on explanations. These were adjusted by science teacher experts' judgment, grouping some elements because of the role played in an explanation. For instance, the examples, graphs, images and experiments were organized together as constituents which illustrated or clarified aspects/properties of the concept being explained. Table 1 details the process.

Table 1. Criteria from literature review and process

\begin{tabular}{|c|c|}
\hline Criterion & Process \\
\hline (1) Explanation aims & Deleted \\
\hline (2) Explanation context & Deleted \\
\hline (3) Clarity & Maintained \\
\hline (4) Coherence and cohesion & Maintained \\
\hline (5) Sequence & Maintained \\
\hline (6) Accuracy & Maintained \\
\hline (7) Links with learners' prior ideas & \multirow{2}{*}{ Grouped } \\
\hline (8) Links with learners' life & \\
\hline (9) Using examples & \multirow{3}{*}{ Grouped } \\
\hline $\begin{array}{l}\text { (10) Using experiment and demonstra- } \\
\text { tion }\end{array}$ & \\
\hline (11) Using graph and imagery & \\
\hline (12) Using metaphor and analogy & \multirow{2}{*}{ Grouped } \\
\hline (13) Using simulation and model & \\
\hline (14) Using body gestures & \multirow{2}{*}{ Grouped } \\
\hline (15) Inflections in voice & \\
\hline $\begin{array}{l}\text { (16) Approaching misconceptions as } \\
\text { learning opportunities }\end{array}$ & Maintained \\
\hline (17) Summary of the explanation & Deleted \\
\hline
\end{tabular}


The same process worked with criteria 7 and 8,12 and 13,14 and 15 . The criteria 1,2 , and 17 were removed because it would not be possible to observe them in a teaching episode. The experts suggested including the criteria of completeness and sufficiency, which implied that the components of the explanation should be enough to understand the targeted concept. Thus, a ten-criterion version rubric was obtained, and we called it REC (Rubric for formative assessment of Explanations of scientific Concepts).

REC was tested in a pilot study with 17 science lessons videotaped in different real teaching contexts by beginning teachers. This led to 60 explanations in total as a lesson contained more than one explanation. The coding system was double-blinded, interrater reliability was calculated and Pearson's correlations were used for analysis. The internal consistency (reliability) of the rubric was $\alpha=0.60(n=10)$, to which every element had contributed. In line with the literature review, reorganization of the elements based on their correlations was done instead of deletion. After this pilot test, REC was further validated by expert panel revision. Instrument developers at The National Teacher Assessment System for public education in Chile collaborated. They suggested some language modification and re-ordering of some performance levels. This last version (see Appendix) was applied to forty of the pre-service teachers' microteaching episodes recorded.

In order to assure reliability, $100 \%$ of the videos were blind double-coded. Inter-rater agreement was $80.35 \%$. The rubric was found to be reliable for this group $(\alpha=.77, n=10)$ and all the elements contributed to its internal consistency. No element, if deleted, would have substantially increased the reliability. Around half of the correlations between the elements $(E)$ were statistically significant $(p<$. 05 ), and all elements were statistically significantly correlated with the total $(\mathrm{T})$ score (Table 2, presented in the next page). Each level of assessment was used at least once, which supports their applicability and pertinence to assess pre-service teacher explanations.
Table 2. Correlation matrix of the final rubric

\begin{tabular}{|c|c|c|c|c|c|c|c|c|c|c|c|}
\hline & E1 & E2 & E3 & E4 & E5 & E6 & E7 & E8 & E9 & E10 & $\mathrm{T}$ \\
\hline E1 & & .13 & -.03 & .46 & .15 & .57 & .33 & .16 & .34 & .41 & .65 \\
\hline E2 & .13 & & .47 & .55 & .62 & .36 & .17 & .16 & .30 & .29 & .66 \\
\hline E3 & -.03 & .47 & & .20 & .47 & .28 & .07 & .11 & $\overline{.08}$ & .10 & .41 \\
\hline E4 & .46 & .55 & .20 & & .51 & .43 & .21 & .35 & .37 & .12 & .69 \\
\hline E5 & .15 & .62 & .47 & .51 & & .34 & .17 & .23 & .17 & -.06 & .56 \\
\hline E6 & .57 & .36 & .28 & .43 & .34 & & .23 & .13 & .34 & .41 & .73 \\
\hline E7 & .33 & .17 & .07 & .21 & .17 & .23 & & .16 & .33 & .13 & .54 \\
\hline ES & .16 & .16 & .11 & .35 & .23 & .13 & .16 & & .18 & .14 & .41 \\
\hline E9 & .34 & .30 & -.08 & .37 & .17 & .34 & .33 & .18 & & .21 & .57 \\
\hline E10 & .41 & .29 & .10 & .12 & -.06 & .41 & .13 & .14 & .21 & & .52 \\
\hline
\end{tabular}

\section{RESULTS}

The participants' initial microteaching episodes showed a varied outline, featuring high and low scores in the criteria. There were a few participants with obtained high scores, however, the general pattern observed was based on medium levels of performance when marked against the rubric. Most of the elements that pre-service teachers showed - at the moment of making concepts explicit through explanations - were half achieved.

The minimum score obtained in a microteaching explanation episode was 5 out of 20 , the maximum 17 , and the standard deviation was 3.38 .

The rubric elements that were the most developed in this group were the sequence of the explanation (SQ3) and using an example, graph or image in the explanation (SQ8). On the contrary, difficulties were found in using analogies, metaphors or models, and approaching misconceptions as learning opportunities for making concepts explicit to the learners. The other criteria were considered to be at a medium level.

After the workshop, the participants' final microteaching episodes presented a wider spectrum in the elements for making concepts explicit through explanations. The minimum score in the whole group was 6 out of 20, the maximum was 19 , with a standard deviation of 3.38 .

The whole groups' pre and post scores are shown in Figure 1. There were score criteria (SQ) with a marked improvement after the workshop in some (i.e. SQ1, SQ6), almost no advance in others (i.e. SQ3, SQ5) or a decrease in a criterion (SQ8).

If we compare the means of the pre and 
International Journal of Cognitive Research in Science, Engineering and Education (IJCRSEE), 6(3), 35-47

post scores, the pre-service teachers' explanations were rated higher after the workshop than at the beginning (mean pre-test $=10.1$, SD $=3.38$; mean post-test $=14.65 ; \mathrm{SD}=3.38$ ). The difference was 4.55 points. The effect size was high $(\mathrm{d}=1.34)$ (Cohen's delta).

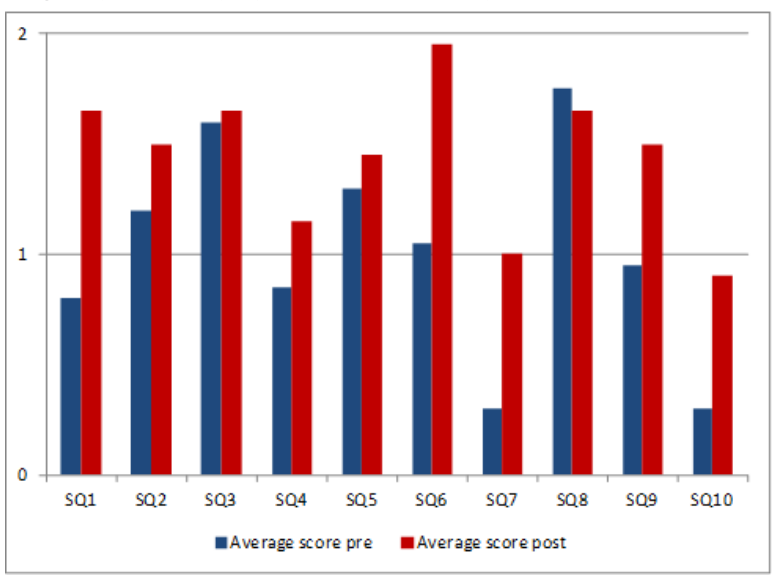

Figure 1. Comparison of scores pre and post work-shop using the rubric REC

One-way ANOVA identified significant differences between the scores obtained at the pre and post measurements $(\mathrm{F}=16.54, \mathrm{df}=39$, $\mathrm{p}<.001$ ), as shown in Table 3. Thus, there were changes in participant teachers' ways of explaining after peer assessment based on the rubric, which suggest an advance in this crucial teaching practice.

Table 3. ANOVA one-way pre and post workshop

\begin{tabular}{lccccc}
\hline & $\begin{array}{c}\text { Sum of } \\
\text { Squares }\end{array}$ & df & $\begin{array}{c}\text { Mean } \\
\text { Square }\end{array}$ & F & Sig. \\
\hline $\begin{array}{l}\text { Between } \\
\text { Groups }\end{array}$ & 189.225 & 1 & 189.225 & 16.540 & .000 \\
\hline $\begin{array}{l}\text { Within } \\
\text { Groups }\end{array}$ & 434.750 & 38 & 11.441 & & \\
\hline Total & 623.975 & 39 & & & \\
\hline
\end{tabular}

Looking at case-to-case instances, only two pre-service teachers had difficulties with improving their initial score. Otherwise, the participants with low initial scores showed the greatest improvements at the end of the workshop. This suggests that formative peer assessment based on the rubric was especially appropriate for participants with greater difficulties in making scientific concepts explicit through explanations.

Regarding the general pattern, the majority of elements had a better score after the peer assessment workshop. Nonetheless, the weakest criteria at the beginning (SQ7, SQ10) were also the lowest criteria once the workshop ended. This suggests those elements need more support to be performed in a high level by pre-service teachers. Perhaps explanation based on metaphors, analogies or models require more refined content knowledge, which was not the focus of this workshop. They might also require extra time and dedicated interventions based on the intersection of pedagogical and content knowledge to reach the level expected by the rubric.

\section{DISCUSSION}

The rubric presented in this paper was useful in identifying strengths and areas for further development in pre-service teachers explanations. Making scientific concepts explicit through metaphors, analogies or models is relevant for teaching from a cognitive perspective, because they require higher-order thinking skills and flexibility of thinking (Ogborn et al., 1996). Moreover, they enhance students' representation and mental model construction (Aubusson, Harrison and Ritchie, 2006; Danielsson, Löfgren and Pettersson, 2018). However, they need a focused strategy to be improved in teacher education. Teachers' content knowledge has a role in their instructional representations (Danielsson, Löfgren and Pettersson, 2018). Perhaps a well-integrated, precise and intellectually challenging understanding of science would favor cognitively oriented teaching practice through explanations. Pedagogical experience is relevant for designing student-centered teaching practices (Koteva-Mojsovska and Nikodinovska, 2015), including simulated teaching practices as in our study.

In this paper, the easiest elements of the pattern in which pre-service teachers made scientific concepts explicit through explanations were clarity (SQ1) and connection with students' prior knowledge and experience (SQ6). After the workshop the rubric detected clearer explanations, which were connected with students' prior understandings and constructed from a synergy of teachers' and students' ideas - which is a prominent principle in a constructivist approach for science education (Geelan, 2012).

Otherwise, the rubric detected one element of explanation without improvement after peer assessment; using examples, graphic representations and images. These were the strongest elements at the beginning of the workshop. However, the participants reported 
that after peer discussion about the characteristics of cognitively challenging examples, a few of them were more confident to use other resources such as analogies in the final microteaching episode, which might explain the decrease.

In summary, the development and application of the rubric allowed the diagnosis and improvement of participants' explanations in terms of explanatory clarity, coherence and cohesion of parts, sequence and sufficiency regarding the pedagogical aim, connection with students' prior ideas or experiences, and use of non-verbal language for representation and emphases.

Regarding the limitations of this research, as the participant selection was not randomized but voluntary based on a workshop invitation, statistical analysis such as factor analysis of the rubric were not used. Additionally, a comparison group was not available and the participants could abandon the workshop at anytime for ethical reasons. Thus, only data from participants with a minimum of 6 out to 10 sessions attended was considered for the results, so the initial sample size was reduced. For further research, better incentives for participants to remain during the workshops will be crucial.

The numerical comparison obtained through the rubric was based solely on an element's absence, presence and a quality aspect when performed. Hence, each element could have a score of 0,1 or 2 . Thus, only for comparative purposes can we establish a general pattern designed to give feedback to pre-service teachers to enable improving the weak elements. This is a limitation of other potential uses of the rubric such as promotion of teachers or other high-stake consequences.

Otherwise, considering explaining as a central competence for science teaching (Geelan, 2012), the present study contributes evidence for developing high-leverage practice before science teachers face the multiple challenges of real school settings. The study presented here highlights the relevance of preparing new teachers with varied strategies for making concepts explicit in the classroom. The rubric constructed for formative assessment is a tool for teacher education.

Moreover, the present study opens a discussion surrounding Pedagogical Content Knowledge (PCK) development in pre-service teachers. Making scientific concepts explicit through teaching requires PCK and practical experience. Shulman's postulates (1986) have remarked that PCK, as the amalgam between content, pedagogical and context knowledge, needs teaching practice and synergy to be crafted. The present research resonates with this, but expands the argument. Pedagogical Content Knowledge for making scientific concepts explicit for teaching can be developed during initial teacher education, if targeted practices are decomposed and rehearsed in protected formative context. Teaching practice in simulated settings might be introduced as a resource in the early stages of teacher education, which opens new research questions.

The present research also contributes to help fill the gap in the literature concerning the construction of explanations by science pre-service teachers - particularly regarding the elements for making scientific concepts explicit. Although the literature review suggested some features of effective explanations, such as adequacy to the audience (Norris et al., 2005; Sevian and Gonsalves, 2008) and the giving of examples (Buckley, 2000; Ogborn et al., 1996), no prior reference was found on how to transform those elements into assessment criteria for formative purposes in teacher education.

This paper also provides an organized and conceptually valid rubric to formatively assess pre-service science teacher explanations. The rubric was designed for diagnosing and intervening in teacher education, but also as a progress monitoring instrument, which is a novel contribution to the field of research in education and the practice of teaching.

\section{CONCLUSIONS}

Regarding the research question about the elements of pre-service teachers' explanations in a simulated context, this study has documented some diverse criteria of science teachers' explanations present in the cognitive science literature and described their assessment within the frame of the development of a rubric for teacher education. The findings showed the explanation strengths of pre-service teachers in explaining based on examples, graphs and images. However, difficulties were found in using and improving analogies, metaphors, and models, and approaching misconceptions as learning opportunities, which have to be addressed.

The rubric REC grouped structural and supportive elements in three levels of performance, based on conceptual features and the function they have on sharing and constructing meaning in the explanation. This organi- 
zation answers the second research question; Can the elements be grouped in general constructs? (see REC in Appendix).

The third question of this study referred to the extent to which the elements of explanations can be organized and improved. The instrument has detected patterns and changes in simulating a high-leverage teaching practice; making scientific concepts explicit through explanations. This sensitive detection allows monitoring of constraints and advances during teacher education. There were statistically significant changes in participant teachers' ways of explaining after peer assessment, which suggest an advance in this crucial teaching practice. A large effect size was found (notwithstanding the small sample).

Thus, from this work, we recommend that teacher educators give opportunities to simulate, rehearse and assess teaching practices conducive to learning with a formative purpose, such as explaining for the classroom.

It is important to highlight that explanations for the classroom are different from scientific explanations. It is not enough to know explanations from science to explain successfully in the classroom. One of the critical aspects of teacher education is helping pre-service teachers to develop knowledge integrated with skills for teaching. Simulating explanations for the science classroom synergizes content knowledge and pedagogical content knowledge in one practice that has a strong influence on learning. Therefore, it is necessary that teacher education provides the learning scenarios for this to happen. We have described in this work the decomposition of practice for helping pre-service teachers to build skills and confidence, through formative peer assessment facilitated by the rubric REC, which we suggest especially for their weaknesses.

We know that school contexts present several challenges - many times the complex and simultaneous demands of real classrooms are shocking for new teachers. Hence, we recommend gradually introducing pre-service teachers to real settings of practice to allow them to orchestrate the bits and pieces needed for teaching diverse groups of students with different conditions and needs.

Simulation of relevant teaching practices, as in our study with explanations, together with a climate of constructive assessment and a detailed analysis of teaching practices can not only improve the preparedness to teach, but also help to build a culture of formative peer assessment with instruments such as
REC that diagnoses, facilitates and monitors changes in high-leverage teaching practices.

Besides, this study echoes with the increased relevance of student-centered teaching approaches, not only in schools but also in teacher preparation programs. 
Valeria M. Cabello (2018) - Making scientific concepts explicit through explanations: simulations of a highleverage practice in teacher education

International Journal of Cognitive Research in Science, Engineering and Education (IJCRSEE), 6(3), 35-47

\section{APPENDIX}

Rubric for formative assessment of Explanations of scientific Concepts (REC). Adapted from Cabello, (2013)

\begin{tabular}{|c|c|c|c|}
\hline Criteria & Level 0 & Level 1 & Level 2 \\
\hline SQ1 Clarity & $\begin{array}{l}\text { The explanation does not } \\
\text { complete the levels } 1 \text { or } 2 \text {, } \\
\text { or the explanation is con- } \\
\text { fusing, vague or tautologi- } \\
\text { cal }\end{array}$ & $\begin{array}{l}\text { First the explanation describes } \\
\text { the concept, then the name or } \\
\text { definition comes, } \\
\text { or } \\
\text { The explanation language is } \\
\text { understandable for the learners }\end{array}$ & $\begin{array}{l}\text { First the explanation describes } \\
\text { the concept, then the name or } \\
\text { definition comes, } \\
\text { and } \\
\text { The explanation language is } \\
\text { understandable for the learners }\end{array}$ \\
\hline $\begin{array}{l}\text { SQ2 Coher- } \\
\text { ence and co- } \\
\text { hesion }\end{array}$ & $\begin{array}{l}\text { The explanation does not } \\
\text { complete the levels } 1 \text { or } 2\end{array}$ & $\begin{array}{l}\text { Every part of the explanation } \\
\text { has a relation (i.e. } \\
\text { cause/consequence, inclu- } \\
\text { sion/exclusion, differentiation/ } \\
\text { similarity) with the next part, } \\
\text { or } \\
\text { The explanation has strong } \\
\text { unifying ties }\end{array}$ & $\begin{array}{l}\text { Every part of the explanation } \\
\text { has a relation (i.e. } \\
\text { cause/consequence, inclu- } \\
\text { sion/exclusion, differentiation/ } \\
\text { similarity) with the next part, } \\
\text { and } \\
\text { The explanation has strong } \\
\text { unifying ties }\end{array}$ \\
\hline $\begin{array}{l}\text { SQ3 } \\
\text { quence }\end{array}$ & $\begin{array}{l}\text { The explanation does not } \\
\text { complete the levels } 1 \text { or } 2\end{array}$ & $\begin{array}{l}\text { The explanation has a pro- } \\
\text { gressive (logical) sequence, } \\
\text { or } \\
\text { The ideas in the explanation } \\
\text { scaffold the construction of } \\
\text { the concept }\end{array}$ & $\begin{array}{l}\text { The explanation has a pro- } \\
\text { gressive (logical) sequence, } \\
\text { and } \\
\text { The ideas in the explanation } \\
\text { scaffold the construction of } \\
\text { the concept }\end{array}$ \\
\hline
\end{tabular}

SQ4 Cor- The explanation contains rectness

inaccuracies that drive learners to mistakes

or

The explanation contains a

conceptual error

\begin{tabular}{lcc}
\hline $\begin{array}{l}\text { SQ5 Com- } \\
\text { pleteness }\end{array}$ & $\begin{array}{c}\text { The explanation shows } \\
\text { mainly elements not con- } \\
\text { tributing to the construc- } \\
\text { tion of the concept }\end{array}$ & $\begin{array}{l}\text { The explanation shows some } \\
\text { elements contributing to the } \\
\text { construction of the concept }\end{array}$ \\
$\begin{array}{l}\text { SQ6 Connec- } \\
\text { then with }\end{array}$ & $\begin{array}{l}\text { The explanation does not } \\
\text { complete the levels } 1 \text { or } 2\end{array}$ & $\begin{array}{l}\text { The teacher identifies stu- } \\
\text { dents' own ideas or remarks } \\
\text { learners' }\end{array}$ \\
& & $\begin{array}{l}\text { leveryday life facets } \\
\text { related to the concept without } \\
\text { explicit connections (i.e. inte- } \\
\text { gration, confrontation, etc.) to } \\
\text { the explanation }\end{array}$
\end{tabular}

The explanation does not contain inaccuracies

or

There are some generalisations which are essential for

the learning process

The explanation shows the

main elements contributing to

the construction of the concept

The teacher identifies students' own ideas or remarks learners' everyday life facets

related to the concept,

\section{and}

makes explicit connections

(i.e. integration, confrontation, etc.) to the explanation 
Valeria M. Cabello (2018) - Making scientific concepts explicit through explanations: simulations of a highleverage practice in teacher education International Journal of Cognitive Research in Science, Engineering and Education (IJCRSEE), 6(3), 35-47

\begin{tabular}{|c|c|c|c|}
\hline Criteria/level & Not achieved (0) & Half achieved (1) & Achieved (2) \\
\hline $\begin{array}{l}\text { SQ7 Meta- } \\
\text { phor, analo- } \\
\text { gy, simula- } \\
\text { tion or model } \\
\text { usage }\end{array}$ & $\begin{array}{l}\text { The explanation does } \\
\text { not contain a correct } \\
\text { analogy, metaphor, sim- } \\
\text { ulation or model, }\end{array}$ & $\begin{array}{l}\text { The explanation contains a } \\
\text { correct analogy, metaphor, } \\
\text { simulation or model, but } \\
\text { the concept features relat- } \\
\text { ed to the analogy, meta- } \\
\text { phor, simulation or model } \\
\text { are not evident }\end{array}$ & $\begin{array}{l}\text { The explanation contains a correct } \\
\text { analogy, metaphor, simulation or } \\
\text { model, } \\
\text { and } \\
\text { The concept features related to the } \\
\text { analogy, metaphor, simulation or } \\
\text { model are clear and evident }\end{array}$ \\
\hline $\begin{array}{l}\text { SQ8 Exam- } \\
\text { ple, experi- } \\
\text { ment, graph } \\
\text { or image us- } \\
\text { age }\end{array}$ & $\begin{array}{l}\text { The explanation does } \\
\text { not complete the levels } \\
1 \text { or } 2\end{array}$ & $\begin{array}{c}\text { The explanation includes } \\
\text { an example, graph or im- } \\
\text { age to support the expla- } \\
\text { nation, } \\
\text { but } \\
\text { The concept features re- } \\
\text { lated to the example, graph } \\
\text { or image are not illustrated }\end{array}$ & $\begin{array}{l}\text { The explanation includes an ex- } \\
\text { ample, graph or image to support } \\
\text { the explanation, } \\
\text { and } \\
\text { The concept features related to the } \\
\text { example, graph or image are illus- } \\
\text { trated }\end{array}$ \\
\hline $\begin{array}{l}\text { SQ9 Ges- } \\
\text { tures and } \\
\text { speech usage }\end{array}$ & $\begin{array}{l}\text { The explanation does } \\
\text { not complete the levels } \\
1 \text { or } 2\end{array}$ & $\begin{array}{l}\text { The teacher uses gestures } \\
\text { to support the explanation, } \\
\text { or } \\
\text { The teacher uses the voice } \\
\text { or speech pace to highlight } \\
\text { some elements of the ex- } \\
\text { planation }\end{array}$ & $\begin{array}{c}\text { The teacher uses gestures to sup- } \\
\text { port the explanation, } \\
\text { and } \\
\text { The teacher uses the voice or } \\
\text { speech pace to highlight some } \\
\text { elements of the explanation }\end{array}$ \\
\hline $\begin{array}{l}\text { SQ10 Mis- } \\
\text { conception as } \\
\text { a learning } \\
\text { opportunity }\end{array}$ & $\begin{array}{l}\text { The explanation does } \\
\text { not complete the levels } \\
1 \text { or } 2\end{array}$ & $\begin{array}{l}\text { The teacher shows a mis- } \\
\text { conception or common } \\
\text { mistake without } \\
\text { encouraging students to } \\
\text { leam from this }\end{array}$ & $\begin{array}{c}\text { The teacher shows a misconcep- } \\
\text { tion or common mistake, } \\
\text { and } \\
\text { addresses how students can leam } \\
\text { from this }\end{array}$ \\
\hline
\end{tabular}

\section{ACKNOWLEDGEMENTS}

Authors would like to thank Conicyt PAI project 821320002, Dr. Dante Cisternas and Cristian Arnés for their valuable support over the course of this study. Instrument developers at The National Teacher Assessment System for public education in Chile collaborated with the revision of the rubric REC.

\section{Conflict of interests}

The authors declare no conflict of interest.

\section{REFERENCES}

Aubusson, P. J., Harrison, A. G., \& Ritchie, S. M. (2006). Metaphor and analogy in science education. Dordrecht: Springer. https://link.springer. com/content/pdf/10.1007/1-4020-3830-5_1.pdf

Ball, D. L. \& Forzani, F. M. (2011). Building a common core for learning to teach and connecting profes- sional learning to practice. American Educator, 35(2), 17-39. https://files.eric.ed.gov/fulltext/ EJ931211.pdf

Buckley, B. C. (2000). Interactive multimedia and model-based learning in biology. International Journal of Science Education, 22(9), 895-935. https://doi.org/10.1080/095006900416848

Baglama, B., Yucesoy, Y., Uzunboylu, H., \& Özcan, D. (2017). Can infographics facilitate the learning of individuals with mathematical learning difficulties?. International Journal of Cognitive Research in Science, Engineering and Education/IJCRSEE, 5(2), 119-127. https://doi. org/10.5937/IJCRSEE1702119B

Cabello, V. M. (2013). Developing skills to explain scientific concepts during initial teacher education: the role of peer assessment. Unpublished Doctoral dissertation, University of Dundee. https://discovery.dundee.ac.uk/ws/portalfiles/ portal $/ 2250078$

Carrascosa, J. (2006). El problema de las concepciones alternativas en la actualidad (parte III). Revista Eureka sobre Enseñanza y Divulgación de las Ciencias, 3(1), 77-88. https://revistas.uca.es/index.php/eureka/article/view/3883

Charalambous, C. Y., Hill, H. C. \& Ball, D. L. (2011). Prospective teachers' learning to provide instructional explanations: how does it look and 
what might it take?. Journal of Mathematics Teacher Education, 14(6), 441-463. https://doi. org/10.1007/s10857-011-9182-z

Cook, M. P. (2006). Visual representations in science education: The influence of prior knowledge and cognitive load theory on instructional design principles. Science Education, 90(6), 10731091. https://doi.org/10.1002/sce.20164

Danielson, C. (2013). The framework for teaching evaluation instrument. Princeton: The Danielson group http://www.loccsd.ca/ div15/wp-content/ uploads/2015/09/2013-framework-for-teachingevaluation-instrument.pdf

Danielsson, K., Löfgren, R., \& Pettersson, A. J. (2018). Gains and Losses: Metaphors in Chemistry Classrooms. In Tang, K. S. \& Danielsson, K. (Eds.), Global developments in literacy ressearch for science education (pp. 219-235) Springer, Cham. https://doi.org/10.1007/978-3319-69197-8 14

Dawes, L. (2004). Talk and learning in classroom science. International Journal of Science Education, 26(6), 677-695. https://doi. org/10.1080/0950069032000097424

Feynman, R. (1994) Six Easy Pieces; Essentials of Physics Explained by Its Most Brilliant Teacher. New York: Helix Books. https://www.biblio. com/six-easy-pieces-by-feynman-richard-p/ work/112435

Geelan D. (2012) Teacher Explanations. In B. Fraser, K. Tobin \& C. McRobbie (Eds.), Second international handbook of science education (pp. 987-999). Springer, Dordrecht. https://doi. org/10.1007/978-1-4020-9041-7 65

Geelan, D. (2013). Teacher explanation of physics concepts: A video study. Research in Science Education, 43(5), 1751-1762. https://doi.org/10.1007/ s11165-012-9336-8

Koteva-Mojsovska, T. \& Nikodinovska-Bancotovska, S. (2015). The effects of the pedagogical expperience on the quality of teacher education International Journal of Cognitive Research in Science, Engineering and Education, 3(2), 4146. http://www.ijcrsee.com/index.php/ijcrsee/ article/view/95

Kozma, R. (2003). The material features of multiple representations and their cognitive and social affordances for science understanding. Learning and Instruction, 13(2), 205-226. https://doi. org/10.1016/S0959-4752(02)00021-X

Larkin, D. (2017). Planning for the elicitation of students' ideas: A lesson study approach with preservice science teachers. Journal of Science Teacher Education, 28(5), 425-443. https://doi. org/10.1080/1046560X.2017.1352410

Legare, C. H., Gelman, S. A., \& Wellman, H. M. (2010). Inconsistency with prior knowledge triggers children's causal explanatory reasoning. Child Development, 81(3), 929-944. https://doi. org/10.1111/j.1467-8624.2010.01443.x

Norris, S. P., Guilbert, S. M., Smith, M. L., Hakimelahi, S., \& Phillips, L. M. (2005). A theoretical framework for narrative explanation in science. Science Education, 89(4), 535-563. https://doi. org/10.1002/sce. 20063

Mayer, R. E., \& Jackson, J. (2005). The case for coherence in scientific explanations: Quantitative details can hurt qualitative understanding. Journal of Applied Experimental Psychology, 11(1), 13 18. http://psycnet.apa.org/buy/2005-02947-002
Martin, R., Sexton, C., \& Gerlovich, J. (2009). Teaching science for all children: methods for constructing understanding (4 ${ }^{\text {th }}$ Ed.). Boston: Allyn and Bacon. https://www.pearson.com/us/higher-education/program/Martin-Teaching-Science-forAll-Children-Inquiry-Methods-for-Constructing-Understanding-4th-Edition/PGM121469. html

Marzano, R., Pickering, D., \& Pollock, J. (2001). Classroom instruction that works. Alexandria, VA: ASCD Press https://www.pearson.com/ us/higher-education/product/Marzano-Classroom-Instruction-that-Works-Research-BasedStrategies-for-Increasing-Student-Achievement/9780131195035.html

Mohan, R. (2013). Innovative science teaching for physical science teachers ( $3^{\text {rd }} \mathrm{Ed}$.). India: Prentice Hall. https://www.bookdepository.com/ Innovative-Science-Teaching-For-PhysicalScience-Teachers-3Rd-Edition-Radha-Mohan/9788120331570

O'Flaherty, J., \& Beal, E. M. (2018). Core competencies and high leverage practices of the beginning teacher: A synthesis of the literature. Journal of Education for Teaching, 44(4), 461-478. https:// doi.org/10.1080/02607476.2018.1450826

Ogborn, J., Kress, G., \& Martins, I. (1996). Explaining science in the classroom. McGraw-Hill Education (UK). http://sro.sussex.ac.uk/27106/

Patton, M. (2001). Qualitative Evaluation and Research Methods ( ${ }^{\text {rd }}$ Ed.). Newbury Park, CA: Sage Publications. http://psycnet.apa.org/record/1990-97369-000

Podolefsky, N.F. \& Finkelstein, N. D. (2007). Analogical scaffolding and the learning of abstract ideas in physics: Empirical studies. Physics Review Studies - Physics Education Research, 3, 1-12. https://journals.aps.org/prper/pdf/10.1103/PhysRevSTPER.3.010109

Rodrigues, R. F., \& Pereira, A. P. d. (2018). Explicações no ensino de ciências: revisando o conceito a partir de três distinções básicas. Ciência \& Educação (Bauru), 24, 43-56. http://dx.doi. org/10.1590/1516-731320180010004

Rodrigues, S. (2010). Exploring talk. Identifying register, coherence and cohesion. In S. Rodrigues (Ed.), Using Analytical Frameworks for Classroom Research (Vol. 1). London: Routledge http://nrl.northumbria.ac.uk/2660/

Roth, W. - M., \& Welzel, M. (2001). From activity to gestures and scientific language. Journal of Research in Science Teaching, 38(1), 103-136 https://doi.org/10.1002/10982736(200101)38:1<103::AID-TEA6>3.0.CO;2G

Sevian, H., \& Gonsalves, L. (2008). Analysing how scientists explain their research: A rubric for measuring the effectiveness of scientific explanations. International Journal of Science Education, 30(11), 1441-1467. https://doi. org/10.1080/09500690802267579

Shulman, L. S. (1986). Those who understand: Knowledge growth in teaching. Educational Researcher, 15(2), 4-14. https://doi. org/10.3102/0013189X015002004

Snyder, J. L. (2000). An investigation of the knowledge structures of experts, intermediates and novices in physics. International Journal of Science Education, 22(9), 979-992. https://doi. org/10.1080/095006900416866 
Valeria M. Cabello (2018) - Making scientific concepts explicit through explanations: simulations of a highleverage practice in teacher education

International Journal of Cognitive Research in Science, Engineering and Education (IJCRSEE), 6(3), 35-47

Smith, D. C. (2000). Content and pedagogical content knowledge for elementary science teacher educators: Knowing our students. Journal of Science Teacher Education, 11(1), 27-46. https:// doi.org/10.1023/A:1009471630989

Thagard, P. (1992). Analogy, explanation, and education. Journal of Research in Science Teaching, 29(6), 537-544. https://doi.org/10.1002/ tea.3660290603

Treagust, D., \& Harrison, A. (1999). The genesis of effective scientific explanations for the classroom. In J. Loughran (Ed.), Researching teaching: Methodologies and practices for understanding pedagogy. London: Routledge. https://www.taylorfrancis.com/books/e/9781135700799/chapter s/10.4324\%2F9780203487365-5

Wenham, M. (2005). Understanding primary science: ideas, concepts and explanations. London: SAGE. https://eric.ed.gov/?id=ED488824

Windschitl, M., Thompson, J., Braaten, M., \& Stroupe, D. (2012). Proposing a core set of instructional practices and tools for teachers of science. Science Education, 96(5), 878-903. https://doi. org/10.1002/sce. 21027

Windschitl, M., Thompson, J., \& Braaten, M. (2008). Beyond the scientific method: Model-based inquiry as a new paradigm of preference for school science investigations. Science Education, 92(5), 941-967. https://doi.org/10.1002/ sce. 20259

Wu, H. K., \& Shah, P. (2004). Exploring visuospatial thinking in chemistry learning. Science Education, 88(3), 465-492. https://doi.org/10.1002/ sce. 10126 